\title{
A case Study of Curriculum Design for English Majors Based on Graduates' Needs Analysis
}

\author{
Dan $\mathrm{ZHOU}^{1, a}$, Wei $\mathrm{HE}^{2, \mathrm{~b}}$ \\ ${ }^{1}$ School of Foreign Languages, Wuhan Textile University, Wuhan, 430073, China \\ ${ }^{2}$ School of Foreign Languages, Wuhan Textile University, Wuhan, 430073, China \\ aemail: Zhoudan@wtu.edu.cn, semail: lexicraze@wtu.edu.cn
}

Key Words: Needs analysis, Curriculum design, English majors, Graduates

\begin{abstract}
This research is based on a case study of Wuhan Textile University (WTU), which has been through a teaching reform since 2010. When general education is brought into the four-year undergraduate curriculum, the curriculum development for English majors is faced with a series of changes and challenges. Through data collection and analysis, this paper gives suggestions on modifying the current curriculum on the basis of students' needs and social needs analysis, and also to evaluate and revise the existing curriculum based on the results of needs analysis.
\end{abstract}

\section{Introduction}

With the development of globalization, the social needs for English major talents in China are changing rapidly in terms of quality and quantity in various fields. [1] As a result, the new requirements challenge English language teaching for English majors. As a matter of fact, EM graduates' future is not so optimistic because they are less competitive than students majored in science and technology. [2]It is obvious that there is a big gap between what EMs learn in the university and what the society expects from EMs. At the same time, many EMs complain that they are not satisfied with the present courses, as the courses can not equip them with much advantage compared with the non-EMs in their occupation. [3]Therefore, it is high time for us to consider the situation of EMs situation in the fast changing and demanding society.

The purpose of this study is to get a whole view of present and potential needs of students and the society, and find out whether the curriculum meet the needs. [4] By analyzing the collected data, it aims to evaluate and revise the existing curriculum to fill this gap and hopes to help improve the situation of course design EMs’ future and job market.

\section{Methodology}

This study is to carry out a survey on the current curriculum for English majors on the background of general education reform, by means of investigating the students' and social needs. The purpose of this study is to get a whole view of present and potential needs of students and the society, and find out whether the curriculum meet the needs.

Research Questions

This research aims to identify, analyze and classify the students' and social needs, in order to examine and improve the current curriculum. This study intends to find out and solve the following questions:

1) What are the English majors' needs in study and social needs for English major talents?

2) To what degree the curriculum align the combined expectations?

3) What suggestions can be proposed to adjust and improve the curriculum for English majors? Participants

This survey in conducted in WTU. As for the social needs, data are collected through an employment survey of English major graduates. In the employment survey, the graduates of 2010 and 2011 are investigated via e-mails with questionnaires enclosed.

Instruments of the Study 
The questionnaire is designed on the basis of the Hutchinson and Waters' needs analysis model (1987), and the items of which share the general and specific features of similar questionnaires. The purpose of the questionnaire is to identify students' understanding, expectations and needs of English learning and teaching.

Data Collection

There are total 100 pieces of questionnaires distributed to the participants in person and 97 pieces are taken back, among which 97 are valid. As for the social needs, this study analyzes the employment survey of the graduates. The survey consists of questionnaires which are sent to the graduates and then recycled by email. Data collected from the questionnaires and the employment survey are typed into the computer and processed and analyzed by Excel.

\section{Results and Discussions}

English Skills Used in Workplace

This research investigates graduates of many occupations in different companies. Table 1 demonstrates graduates’ occupation.

Table 1 Graduates’ occupation

\begin{tabular}{lll}
\hline Occupation & No. & Ratio (\%) \\
\hline Manufacturing & 4 & 4.12 \\
Sales personnel & 12 & 12.37 \\
Marketing/public relations & 3 & 3.09 \\
Administrative staff & 6 & 6.19 \\
Human resource & 5 & 5.15 \\
Financial/auditory people & 4 & 4.12 \\
Clerk & 9 & 9.28 \\
Technician/researcher & 16 & 16.49 \\
Management & 13 & 13.4 \\
Teacher & 6 & 6.19 \\
Consulting & 1 & 1.03 \\
Professionals (lawyer, etc.) & 8 & 8.25 \\
The others & 10 & 10.31 \\
Total & 97 & \\
\hline
\end{tabular}

From the table, we can see that graduates have a wide choice of job comparatively, but some work may not have high requirements for English skills, such as sales personnel, management, and clerical work. Graduates do not have much room to demonstrate their advantages, which is a waste of human resources.

Table 2 English skills used in workplace (multiple choices)

\begin{tabular}{lll}
\hline English skills & No. & Ratio (\%) \\
\hline Material reading & 68 & 70 \\
Oral communication & 49 & 51 \\
Professional material translation & 45 & 46 \\
Business letter writing & 42 & 43 \\
Others & 11 & 11 \\
Total & 97 & \\
\hline
\end{tabular}

As to the aspect of English skills that are often used during work, demonstrated in table 4.2, material reading takes up 70 percent followed by oral communication with 51 percent and professional material translation with 46 percent. 
Table 3 the importance of listening, speaking, reading, writing, translation

\begin{tabular}{ll}
\hline English skills & Average point \\
\hline Speaking & 3.91 \\
Listening & 3.74 \\
Reading & 2.35 \\
Writing & 2.03 \\
Translation & 1.61 \\
\hline
\end{tabular}

Among the four skills, speaking gets the first place with an average point of 3.91, and the other skills in sequence are listening, reading, writing, and translation. Translation gets the lowest average point, but it does not mean translation is not important for EMs, as translation skill is based on the other four skills. It is not hard to find out that listening and speaking are most often used skills in their work.

Social Expectations for EM Graduates

In recent years, many universities have carried out their enlargement plan, and there are more EM graduates than ever before, which poses a great threat to their employment. [5]It doesn't mean that society does not have EM needs, but EMs may not qualify for companies' requirements.

Table 4 the degree of need of EM graduates in companies

(From 1 very much in need to 5 do not need at all)

\begin{tabular}{lll}
\hline Degree & No. & Ratio (\%) \\
\hline 1 & 18 & 19 \\
2 & 48 & 50 \\
3 & 23 & 23 \\
4 & 6 & 6 \\
5 & 2 & 2 \\
Total & 97 & 100 \\
\hline
\end{tabular}

From the investigation, many graduates said that their company needs EMs, as it shows in table 4, but still a considerable 23\% graduates said that EM graduates were not necessarily included in their company. It means that the number of social demands for EM graduates is not that big, and universities should cultivate more qualified talents.

Table 5 the percentage of each skill or ability occupies (multiple choices)

\begin{tabular}{lll}
\hline Skill or ability & No. & Ratio (\%) \\
\hline Speaking & 71 & 73 \\
Word processing ability & 44 & 45 \\
The public relations ability & 37 & 38 \\
Literature level & 20 & 21 \\
Professional knowledge $\quad$ in & finance, & 19 \\
business, etc. & & 20 \\
Computer level & 19 & \\
Planning ability & 15 & 20 \\
Others & 10 & 15 \\
Total & 97 & 10 \\
\hline
\end{tabular}

Companies still expect EM graduates to be very competent in English speaking skill, which takes up about $73 \%$, and the next is the ability to deal with words, which is 45 percent. The following table shows the percentage of each skill or ability that companies expect from EM graduates. The public relations ability is $38 \%$, which means that students should not only learn knowledge and practice their language skills, but also have to learn how to deal with different people.

Suggestions

According to the problems existing in the current curriculum we discussed above, suggestions are proposed in this part to improve the curriculum development. [6] 1) The department can optimize the course arrangement in different grades to balance the credit hours of the three-year major study, such as allocating some credit hours of the sophomore to the junior or senior year. 2) Student-centered principle should be advocated and implemented in learning and teaching activities. 3) As for the teachers, regular training programs and an academic atmosphere can be available to all the teachers. 
As for the job requirements, professions concerning education demand for solid language skills, a fair knowledge of teaching methodology and pedagogy, and communicative ability of instructing. Professions of English Graduates and Main Job Requirements

Table 6 Professions and job requirements

\begin{tabular}{|c|c|}
\hline Professions & Main requirements \\
\hline Education & $\begin{array}{c}\text { Solid language skills, knowledge of teaching } \\
\text { methodology and pedagogy. }\end{array}$ \\
\hline Consulting service, logistics & Relevant interdisciplinary knowledge, language \\
and finance & skills and proficient communicative skills. \\
\hline Research and manufacturing & Reporting writing and translating, relevant \\
& knowledge and fluent oral English. \\
\hline
\end{tabular}

The basic requirements for English majors include adequate language knowledge and skills, proficient communicative ability both in oral and written, international perspective and transferable skills to different professions. With regards to the expected abilities of the graduates, the survey investigated the most important abilities needed in work, and the graduates think the most important abilities at work are critical thinking ability and analyzing ability.

\section{Conclusion}

This research focuses on examining the curriculum with integrated general education for English majors in WTU, on the basis of the needs analysis of students and society, in order to examine whether the curriculum meet the expectations of learning goals, course arrangement and teaching, and propose suggestions on improving the curriculum. [7]Through this research, there come some implications that might be helpful for future English teaching and cultivating more competent EM graduates in order to improve the current situation. [8]There are many limitations in this research. First of all, the participants in this research are limited to graduates of 2010 and 2011. Thirdly, due to the limited sample size, the results may be unreliable and subjective. Some unseen factors, such as students' emotion and attitude may affect the results.

\section{Acknowledgement}

In this paper, the research was sponsored by Foundation of Hubei Educational Committee (Project No. 154017) and Education Development Foundation of Wuhan Textile University (Project No. 141141002).

\section{References}

[1] Brindley. The Role of Needs Analysis in Adult ESL Program Design[M]. Cambridge: Cambridge University Press, 1998.

[2] Ehrmann, S. Beyond Computer Literacy: Implications of Technology for the Content of a College Education[J]. Liberal Education, 2004(4): 6-13.

[3] Marsh, C. J. Key Concepts for Understanding Curriculum [M]. London: The Falmer Press, 1992.

[4] Allen, M. J. Assessing General Education Programs [M]. Bolton: Anker Publishing Company, 2006.

[5] Hutchinson, T. \& Waters, A. English for Specific Purposes [M]. Cambridge: Cambridge 
University Press, 1987.

[6] Laird, T. F. N, Niskode, A. S. \& Kuh, G. D. General Education Courses and the Promotion of Essential Learning Outcomes [A]. Paper presented at the Annual Meeting of the Association for the Study of Higher Education, 2006.

[7] Long, M. H. Second Language Needs Analysis [M]. Beijing: Foreign Language Teaching and Research Press, 2011.

[8] Nunan, D. Tradition and Change in the ELT Curriculum [M].Beijing: Foreign Language Teaching and Research, 2001 